ROCZNIKI PSYCHOLOGICZNE/ANNALS OF PSYCHOLOGY

2020, XXIII, 1, 63-82

DOI: http://dx.doi.org/10.18290/rpsych20231-4

KATARZYNA D. SZUDY

MAŁGORZATA M. PUCHALSKA-WASYL

Institute of Psychology, John Paul II Catholic University of Lublin, Poland

\title{
THE RELATIONSHIP WITH THE FATHER AND THE EMOTIONAL FUNCTIONING OF WOMEN IN ADULTHOOD
}

\begin{abstract}
Some studies, conducted also in Poland, show that the influence of fathers' behavior on their daughters extends beyond childhood. For example, fathers' parental attitudes assessed retrospectively (such as demands, inconsistency, lack of acceptance, and lack of autonomy) are associated with different mental disorders experienced by their adult daughters. The aim of the present study was to determine whether the retrospective evaluation of the relationship with the father explains the emotional functioning of women in early and middle adulthood. The participants were 180 women aged between 20 and 53. We used the Parental Bonding Instrument, the Questionnaire of Retrospective Assessment of Parental Attitudes, and the Trait Personality Inventory. Our findings support a link between the relationship with the father and the emotional functioning of women. In future it would be advisable to broaden the scope of the study by including groups of daughters in adolescence and in late adulthood or women with various problems.
\end{abstract}

Keywords: women; father; bond; parental attitude; anxiety; anger; depression; curiosity.

\section{INTRODUCTION}

The physical attendance of the father and his psychological importance in the family are underestimated by both society and many scientific disciplines. For a long time the issue of paternity has been outside the area of interest of re-

Correspondence concerning this article should be addressed to KATARZYNA D. SZUDY, Department of Personality Psychology, Institute of Psychology, John Paul II Catholic University of Lublin, al. Racławickie 14, 20-950 Lublin, Poland; email: szudy.kkatarzyna@gmail.com; ORCID: https://orcid.org/0000-0002-4033-9530; MatgorZata M. PuChalsKa-WasYL, ORCID: https:// orcid.org/0000-0003-4295-8308. 
searchers (Sitarczyk, 2002). In the life of his daughter, the father undoubtedly plays a very important role, and the mechanism of internalisation seems to be essential. She internalizes her father's behavior towards her and in this way she creates a male schema. It has a significant impact on all areas of her life, both as a girl and teenager, and later in her adult life, too. Using Bandura's (2007) terminology, one can say that a father is a model, showing how his daughter should be loved, respected and treated by other men, and how she should treat them. The basic role of the father is to awaken the daughter's sense of security and stability and adequate self-assessment (Sosnowski, 2009).

Research in father-child relationship, albeit less numerous than that in maternal relationship, yields very interesting results. For example, some researchers highlighted the influence of constructive fathering (understood as father-child closeness, trust, support, low control and high care) on adolescent's well-being, positive adjustment and fewer symptoms of emotional disorders (Adamsons \& Johnson, 2013; Canetti et al., 1997; Kerr et al., 2009; Lucassen et al., 2011). In the other studies depressive symptoms in youth have been linked to impaired father-adolescent relationships (Brennan et al., 2002; Leidy et al., 2011; Shiner $\&$ Marmorstein, 1998). There is also evidence of a link between clinical depression of adolescents and their relations with fathers (Allen et al., 2006; Hale et al., 2005). Pedersen (1994) showed a correlation between high control and low parental care and anxiety disorders, depression, and criminal behavior of adolescents. Leidy et al. (2011) also found that the father's rejection is linked to higher levels of anxiety and depressive symptoms, while the father's acceptance is associated with lower levels of these symptoms. Additionally, it was shown that paternal care is negatively correlated with internalizing problems, somatic complaints and thinking disorders in adolescent girls, whereas father's control positively correlates with social problems (Wajda, 2013). Moreover, difficulties in emotion regulation are more prevalent among adolescents with psychologically controlling fathers (McEwen \& Flouri, 2009). The influence of parental attitudes of fathers and mothers towards their children is long term and it largely goes beyond the period of childhood and adolescence. This is confirmed by a longitudinal study that analyzed parents' support of their children who were entering early adulthood and their sense of satisfaction with life in middle age. It was concluded that the attitude of the father's support promoted a subjective feeling of better health and less depressive symptoms in the second study over 30 years later (Poon \& Zaidman-Zait, 2014). It has been also shown that the father's attitude is important for the development of the child's personality. High neuroticism of a grown-up child positively correlates with the father's demanding and 
inconsistent attitudes and negatively correlates with the autonomy attitude (Plopa, 2016). Fathers' parental attitudes assessed retrospectively are also associated with mental disorders experienced by their adult daughters. In this case, it was found that the father's inconsistent attitude correlated with PTSD symptoms, depressive symptoms, panic reactions, and psychotic disorders. The father's demanding attitude was correlated with all these above-mentioned problems and additionally with somatic disorders, and anorexia. The father's lack of acceptance was associated with symptoms of PTSD, somatic disorders, psychotic disorders, and depressive symptoms. Finally, lack of autonomy correlated in the same way as lack of acceptance, except for depressive symptoms (Pasternak \& Ochojska, 2016). Furthermore, women's choice of career may be more influenced by fathers than mothers (O'Brien et al., 2000). Emotional bonds with fathers may be connected with daughter's developing sense of self-efficacy (Scott \& Mallinckrodt, 2005).

Many studies on family relations have involved groups of people suffering from eating disorders. It has been suggested that the persistence of chronic anorexia nervosa may be linked to a lower level of paternal care (Bulik et al., 2000). Analyses also showed positive correlations between fathers' emotional involvement and the self-esteem of daughters suffering from bulimia nervosa (Meyer \& Gillings, 2004). It has been also proved that there are positive correlations between the emotional involvement of fathers and the femininity of daughters (Józefik et al., 2010). Other studies have shown that the self-esteem of daughters suffering from restrictive anorexia positively correlates with the attitudes of protective and loving fathers, and negatively correlates with the attitude of rejection (Witkowska, 2013).

In the context of the above-mentioned results, the aim of the present study was to determine whether the father's parental attitudes and his bond with his daughter(s) predict the emotional functioning (considered in terms of traits of anxiety, depression, anger and curiosity) of women in early and middle adulthood.

Attitude is defined as "a relatively constant organisation of the cognitive, emotional, motivational and behavioral factors, which determines ... the subject's willingness to react positively or negatively to the environment" (Plopa, 2015, p. 244). Parental attitude is the basic term used to understand the dynamics of the parent-child relationship. There are different typologies of parental attitudes. For example, Roe and Siegelman (1963) described six parental attitudes: protecting, demanding, rejecting, neglecting, causal, and loving. Siegelman (1966) distinguished three main dimensions of parental attitudes: loving, 
demanding, and controlling. In reviewing various typologies presented in the literature, Plopa (2015) concluded that the differentiated influence of parents on their children could be reduced to four basic dimensions: acceptance, protection, demands, and autonomy. The fifth dimension, inconsistency, was added by Plopa on the basis of his own empirical research. As this typology will be analyzed in our empirical study presented further, below we characterize parental attitudes proposed by Plopa.

Acceptance is associated with the free expression of thoughts, feelings and views by the child, and the parents' interest in their child's needs and problems. An adult child regards their parent as an authority, ready to give support, open and not imposing. The opposite is the attitude of rejection which is connected with the lack of acceptance of the child by the parent. In adulthood, such a child remembers relations with a parent as cold, distanced and based primarily on the satisfaction of material needs (Plopa, 2015, 2016). Protection involves treating a child as a weak person and requiring constant care. The parent excessively interferes in the affairs and personal problems of the child, does not believe in her abilities (Plopa, 2015, 2016). An attitude of excessive demands does not account for the predispositions, interests and needs of the child, but requires actions far beyond their capabilities. It is associated with the adult parent's belief that in childhood he or she was accepted by their parents only when they followed their instructions (Plopa, 2015, 2016). The attitude of autonomy is associated with flexible behavior adapted to the child's developmental needs. The parent understands and respects the child's need for privacy and co-decision (Plopa, 2015, 2016). Inconsistency is associated with variability in expressing feelings, opinions and making decisions. The lack of stability in the parent's behavior translates into emotional distancing from the child, hiding problems and difficulties. Such an attitude is not conducive to the development of an adequate level of self-esteem in the child (Plopa, 2015, 2016)).

Apart from parental attitudes, the relationship between the father and his daughter depends on the bond (attachment). Parental attitudes are acquired and can be shaped consciously, while bonding is based on the mechanism of imprinting (Liberska, 2011). The bond between the child and the caregiver is the subject of the attachment theory (Bowlby, 1969/2007). According to this theory the basic element of human nature is a need to create emotional bonds with selected people. This kind of social relationship, initially established between the child and the caregiver and then with other people, is called attachment (Bowlby, 2007). It is established as early as the first year of life. An interaction with the figure of attachment results in the child's expectations, which give rise to internal operat- 
ing models. They influence social functioning in further life, also in adulthood (Liberska, 2011). They have an especially powerful impact on relationships between adults and their own children (Bialecka-Pikul, 2011). Since they were established in early childhood outside the conscious, people are not aware of their influence on the relationships they build (Bowlby, 2007). Ainsworth (1982; Ainsworth \& Bell, 1970) distinguished three basic styles of attachment: secure (B), anxious-avoidant (A) and anxious-ambivalent (C). The type of attachment is diagnosed in young children, observing their reaction to being left alone in an unknown place, to the appearance of a stranger, and to the return of the caregiver after a moment of absence. Secure attachment is typical of children who react with some stress to being separated from the mother and are happy when the mother returns, treating her as a safe base for exploring the environment. Anxious-avoidant attachment is characteristic of children who do not protest when the caregiver leaves, and when he or she returns they do not seek contact with them and do not show trust. Children with the anxious-ambivalent style often react with excessive stress to their mother's disappearance, and at the same time show anger when she returns. They are often frightened, tearful, and unable to explore independently. Main and Solomon (1986) supplemented this classification with disorganized style (D), which combines selected features of A and C types.

Parker, Tupling and Brown (1979) synthesized the views of different theorists and researchers (e.g., Ainsworth, 1982; Bowlby, 2007; Roe \& Siegelman, 1963) and proposed two principal bipolar dimensions of parental characteristics, which contribute to the quality of attachment: care and control/overprotection. One end of the care dimension is defined by empathy, affection, emotional warmth, and closeness, while the other end is defined by indifference, emotional coldness, rejection, and neglect. The control dimension involves, at one end, promotion of independence and autonomy, while the other end is described by overprotection, intrusion, infantilization, excessive contact, and prevention of independent behavior.

The theory of bonds was also formulated in the categories of regulation of emotions. According to this theory, secure attachment enables a child and then an adult to develop the ability to effectively self-regulate emotions. On the other hand, anxious-avoidant and anxious-ambivalent attachments can be related to disturbances in regulating emotions (Żechowski \& Namysłowska, 2008). Emotions play a very important role, mainly in interpersonal relationships and adaptation processes (Eisenberg et al., 1999a; Eisenberg et al., 1999b). Nonetheless, the research on emotional development in adulthood is poor (Olejnik, 2017)). Disor- 
ders related to the processes of regulating emotions, such as behavioral disorders, aggression or depression, are a growing social problem. Emotions motivate behavior and have a significant impact on mental health and well-being (Spielberger \& Reheiser, 2009). Some of their properties, such as high frequency, intensity and duration of negative emotions, as well as low parameters of positive emotions, are dysfunctional and lead to lowered moods (Clark \& Watson, 2012).

According to Spielberger and Reheiser (2009), anxiety, depression, anger, and curiosity are the main indicators of mental suffering and well-being. They define emotions as a complex, qualitatively differentiated, psychobiological state of the organism, characterized by phenomenological and physiological properties. In line with Cattell and Scheier's (1960) distinction, the authors are of the opinion that emotional experience contains two related but conceptually distinct aspects: state and trait. An emotional state is transient, changeable and situationally conditioned, whereas relatively permanent individual differences in the tendency to experience emotional states can be called emotional traits (Spielberger \& Reheiser, 2009, 2004; Spielberger \& Starr, 1994).

The state of anxiety is defined as a transient reaction consisting of conscious feelings of tension, nervousness, and the associated stimulation of the autonomous nervous system. The trait of anxiety is related to individual differences in the propensity to experience anxiety state (Spielberger \& Reheiser, 2004). The notion of depression in this approach refers to feelings of sadness, depression, unhappiness and hopelessness (Litman \& Spielberger, 2003). The trait of depression is related to the propensity to these feelings (Spielberger \& Reheiser, 2009). The state of anger is defined as an emotional state consisting of feelings of varying intensity-from mild irritation to strong rage-accompanied by stimulation of the autonomous nervous system. The trait of anger refers to the individual's tendency to feel anger. It is important to differentiate between anger, hostility, and aggression. Anger is an emotion, hostility is an attitude, and aggression is a behavior, so these notions cannot be identified with each other (Spielberger \& Reheiser, 2004). Curiosity is treated as an emotional and motivational factor stimulating the exploratory behavior of the environment. Its intensity changes over time as a function of perception of novelty, inconsistency, or ambivalence of stimuli. There are two aspects of curiosity: searching for information and looking for experiences or impressions (Spielberger \& Starr, 1994). The state of curiosity is related to the feelings of interest in exploratory activities at a given time. The curiosity trait refers to individual differences in the inclination to experience curiosity (Spielberger \& Reheiser, 2009). 
Given that these four emotions are treated by Spielberger and Reheiser (2009) as main indicators of mental suffering and well-being, and granting that many studies and theories show links between the father's behaviors towards his daughter and her psychosocial functioning, we posed two general hypotheses:

1. The retrospectively assessed parental attitudes of the father explain the trait of anxiety, depression, anger, and curiosity in women.

2. Two retrospectively assessed dimensions of the bond with the father, care, and control, account for the traits of anxiety, depression, anger and curiosity in women.

\section{METHOD}

\section{Participants}

The study involved 180 women aged between 20 and 53 years $(M=30.58$; $S D=9.04)$. Nearly half of the respondents $(46 \%)$ lived in cities with over 100,000 inhabitants, and they were in an average material situation (48\%). The largest number of participants were in a formal relationship (35\%), and only 5 women were divorced. The remaining women were in an informal relationship $(31 \%)$ or were single $(31 \%)$. More than half of the women $(66 \%)$ had no children. The majority of the respondents grew up in a two-parent family and their biological father lived with them $(88 \%)$. The remaining women $(12 \%)$ did not live with their father throughout their childhood-the average age at which daughters stopped living with their fathers was 10 years $(S D=3.12)$. The most common cause was the parents getting divorced (48\%) or the father's death (29\%). All participants provided information about the biological father. In their families of origin there were situations such as the fathers working abroad (30\%), father's alcoholism (24\%), physical (15\%), and emotional (23\%) violence from the father. The fathers of most of the women surveyed are alive, $13 \%$ of them are not.

\section{Procedure}

The participants were selected for the research in two ways. A group of women in early adulthood was invited to take part in the study through oral invitations at the university. A group of women in middle adulthood was selected using the snowball method. They were informed about their anonymity, voluntary participation and the possibility to resign at any time. The participants 
received a set of questionnaires directly from a researcher and completed them at home. The research methods were ordered like this: the Parental Bonding Instrument (PBI), the Questionnaire of Retrospective Assessment of Parental Attitudes (KPR-Roc), and the Trait Personality Inventory (TPI, Form D). They were all paper and pencil versions.

\section{Measurement Methods}

The Parental Bonding Instrument (PBI), by Parker, Tupling and Brown (1979), measures children's attachment to their parents in a retrospective assessment of control and care. The Polish translation and adaptation was done by Oleś (2012). The theoretical basis of the tool is provided by Winnicott's concept, which draws on Bowlby's theory of attachment (Tomasiewicz et al., 2016). The PBI comprises 25 statements on parental behavior, including two subscales: Care (12 items) and Control (13 items). The sense of the scales is compatible with two bipolar dimensions of parental behavior described in the first part of the article (Parker et al., 1979). The measurement is carried out separately for mothers and fathers. In the present study, only the father-evaluation version was used. The answers are marked on a 4-point scale, from 0 to 3: 0-Completely true, 1-Partially true, 2-Partially false, and 3-Completely false. Raw scores for Care range from 0 to 36 points, and for the Control scale from 0 to 39 . Cronbach's alpha coefficients in this study were 0.70 for Care $\alpha$ and 0.72 for Control $\alpha$.

The Questionnaire of Retrospective Assessment of Parental Attitudes (KPR-Roc), developed by Plopa (2016), is used for retrospective assessment of parental attitudes manifested by an adult child. The questionnaire has two versions to assess the attitudes of a father or a mother. The present study makes use of only the father-based version. Both versions contain 50 statements, constituting five subscales: Inconsistency, Acceptance, Autonomy, Protection, and Demands. The sense of the scales is compatible with that described in the first part of the article. For each subscale there are 10 statements. The statements refer to the parent's behavior towards the child, and the answers are marked on a 5-point scale, from A (Definitely he/she was and behaved like that) to E (Definitely he/she was not and did not behave like that). The raw scores range from 10 to 50 on each subscale. Cronbach's alpha coefficients in this study were as follows: Inconsistency $\alpha=0.83$, Acceptance $\alpha=0.78$, Autonomy $\alpha=0.78$, Protection $\alpha=$ $=0.74$, and Demands $\alpha=0.83$. 
The Trait Personality Inventory (TPI) by Spielberger is part of the State Trait Personality Inventory (STPI; Spielberger \& Reheiser, 2003). The Polish translation and adaptation was done by Wrześniewski and Oleś (2005). It is based on Spielberger's concept, which assumes that emotions can be captured as states and traits. The TPI is used to measure emotions understood as a trait. It comprises 40 statements that form four subscales: Anxiety, Anger, Depression, and Curiosity. Each subscale consists of 10 items. TPI statements refer to what the examined person usually feels, the answers are marked on a 4-point scale from 1 (Almost never) to 4 (Almost always). Raw scores on each subscale range from 10 to 40 points. Cronbach's alpha coefficients in this study were as follows: Anxiety $\alpha=0.84$, Anger $\alpha=0.89$, Depression $\alpha=0.84$, and Curiosity $\alpha=0.90$.

\section{RESULTS}

\section{Preliminary Analyses}

The statistical data analyses were done using SPSS (25.0.0.1). First, we calculated the coefficients of kurtosis, skewness, and the Kolmogorov-Smirnov test to each construct. Given that the obtained values for asymmetry and kurtosis between -2 and +2 are considered acceptable to prove normal univariate distribution (George \& Mallery, 2010), Pearson's $r$ and multiple regression analyses were applied.

\section{Regression Analyses}

To verify whether the bond with the father and his parental attitudes assessed retrospectively are correlated with the traits of anxiety, anger, depression, and curiosity in women, Pearson's $r$ was calculated (Table 1).

The results show positive correlations between the women's Anxiety trait and Father's Control and his Inconsistency and Demands. We also found negative correlations between the women's Anxiety and Father's Care and Acceptance and Autonomy. The same pattern of correlations is typical of Anger. A similar pattern is also characteristic for Depression, the exception being the lack of correlation with the father's inconsistency. The pattern of correlation for the Curiosity trait is reversed. Curiosity correlates positively with Father's Care and Acceptance, whereas negatively with Father's Control, Inconsistency and demanding attitude. 
Table 1. Descriptive Statistics and Correlations Between Bond Dimensions, Father's Parental Attitudes and Women's Emotional Traits

\begin{tabular}{lccccccccccccc}
\hline & 1 & 2 & 3 & 4 & 5 & 6 & 7 & 8 & 9 & 10 & 11 & $M$ & $S D$ \\
\hline 1. Care & - & $-.49^{* *}$ & $-.70^{* *}$ & $.82^{* *}$ & $.75^{* *}$ & $.27^{* *}$ & $-.64^{* *}$ & $-.23^{* *}$ & $-.17^{*}$ & $-.21^{* *}$ & $.22^{* *}$ & 20.38 & 10.13 \\
2. Control & & - & $.62^{* *}$ & $-.47^{* *}$ & $-.62^{* *}$ & $.16^{*}$ & $.67^{* *}$ & $.21^{* *}$ & $.22^{*}$ & $.22^{* *}$ & $-.15^{*}$ & 13.54 & 7.66 \\
3. Inconsistency & & - & $-.71^{* *}$ & $-.71^{* *}$ & .01 & $.83^{* *}$ & $.31^{* *}$ & $.24^{* *}$ & .02 & $-.22^{* *}$ & 27.44 & 10.78 \\
4. Acceptance & & & - & $.82^{* *}$ & $.45^{* *}$ & $-.64^{* *}$ & $-.26^{* *}$ & $-.21^{* *}$ & $-.26^{* *}$ & $.19^{* *}$ & 32.16 & 11.87 \\
5. Autonomy & & & & & - & $.26^{* *}$ & $-.77^{* *}$ & $-.16^{*}$ & $-.14^{*}$ & $-.16^{*}$ & .12 & 33.96 & 9.46 \\
6. Protection & & & & & & - & .11 & -.02 & .07 & -.05 & .07 & 26.74 & 7.82 \\
7. Demands & & & & & & & & & & & & & \\
8. Anxiety
\end{tabular}

Note. $* p<0.05, * * p<0.01$.

Additionally, Anxiety positively correlates with Anger and Depression. Anger positively correlates with Depression. The trait of Curiosity correlates negatively with Anxiety and Depression.

To verify whether the bond with the father and his parental attitudes assessed retrospectively explain the traits of anxiety, anger, depression, and curiosity in women, two multiple regression analyses were applied using the stepwise method. These analyses were performed separately because dimensions of bond with the father and paternal attitudes were correlated.

In the first multiple regression two aspects of the bond with the father, care and control were treated as independent variables, whereas women's emotions such as anxiety, anger, depression, and curiosity were dependent variables (Table 2). 
Table 2. Multiple Regression Results for Daughter's Emotional Traits as a Dependent Variable and Father's Care and Control as Independent Variables

\begin{tabular}{lcccc}
\hline \multicolumn{5}{c}{ ANXIETY } \\
& \multicolumn{5}{c}{$R^{2}=.04 ; F(1,178)=9.29 ; p=.003$} \\
(Constant) & \multicolumn{1}{c}{$S E$} & $\mathrm{~B}$ & $t$ & \\
\cline { 2 - 6 } Care & 25.38 & 1.02 & 24.86 & .001 \\
\hline
\end{tabular}

ANGER

\begin{tabular}{|c|c|c|c|c|c|}
\hline \multicolumn{6}{|c|}{$R^{2}=.05 ; F(1,178)=9.43 ; p=.002$} \\
\hline & $B$ & $S E$ & $\mathrm{~B}$ & $t$ & $p$ \\
\hline (Constant) & 18.67 & 0.94 & & 19.78 & .001 \\
\hline Control & 0.19 & 0.06 & .22 & 3.07 & .002 \\
\hline \multicolumn{6}{|c|}{ DEPRESSION } \\
\hline \multicolumn{6}{|c|}{$R^{2}=.04 ; F(1,178)=9.29 ; p=.003$} \\
\hline & $B$ & $S E$ & $\mathrm{~B}$ & $t$ & $p$ \\
\hline (Constant) & 17.37 & 0.98 & & 17.76 & .001 \\
\hline Control & 0.19 & 0.06 & .22 & 3.05 & .003 \\
\hline
\end{tabular}

CURIOSITY

\begin{tabular}{lccccc}
\multicolumn{5}{c}{} & \multicolumn{5}{c}{$R^{2}=.05 ; F(1,178)=9.79 ; p=.002$} \\
& \multicolumn{1}{c}{$B$} & $S E$ & $\mathrm{~B}$ & \multicolumn{1}{c}{$t$} \\
\cline { 2 - 6 } (Constant) & 26.98 & 0.93 & 28.94 & .001 \\
Care & 0.13 & 0.04 & .23 & 3.13 & .002 \\
\hline
\end{tabular}

Note. Only significant predictors are shown.

We found that anxiety in women is explained by the father's care. The care variable is associated with Anxiety negatively, which means that the greater paternal care $(\beta=-.22 ; p<.003)$, the lower Anxiety. The care variable explains $4 \%$ of Anxiety variance. The intensity of Anger in women is explained by Father's Control. Control is related to Anger positively, which means that the higher father's control $(\beta=.22 ; p<.002)$, the greater the intensity of anger. The variable of control explains 5\% of Anger variance. The trait of Depression in women is also explained by Father's Control, which is related to the depression trait positively. Consequently, the greater the intensity of Father's Control $(\beta=.22$; $p<.003$ ), the greater the intensity of the Depression trait. The variable of control explains $4 \%$ of the Depression trait variance. Finally, the intensity of Curiosity in 
women is explained by Father's Care. The variable of care is associated with the Curiosity trait positively, which means that the greater the intensity of Care provided by the father $(\beta=.23 ; p<.001)$, the greater the intensity of the Curiosity trait in his adult daughter. The variable of care explains $5 \%$ of curiosity variance.

In the second multiple regression five parental attitudes of the father: Inconsistency, Acceptance, Autonomy, Protection, and Demands were treated as predictors, whereas women's emotions were dependent variables (Table 3).

Table 3. Multiple Regression Results for Daughter's Emotional Traits as a Dependent Variable and Father's Parental Attitudes as Independent Variables

\begin{tabular}{|c|c|c|c|c|c|}
\hline \multicolumn{6}{|c|}{ ANXIETY } \\
\hline \multicolumn{6}{|c|}{$R^{2}=.10 ; F(1,178)=19.50 ; p<.001$} \\
\hline & $B$ & $S E$ & $\beta$ & $t$ & $p$ \\
\hline (Constant) & 17.611 & 1.21 & & 14.55 & .001 \\
\hline Inconsistency & 0.18 & 0.04 & .31 & 4.41 & .001 \\
\hline \multicolumn{6}{|c|}{ ANGER } \\
\hline \multicolumn{6}{|c|}{$R^{2}=.06 ; F(1,178)=11.66 ; p=.001$} \\
\hline & $B$ & $S E$ & $\beta$ & $t$ & $p$ \\
\hline (Constant) & 17.30 & 1.23 & & 14.06 & .001 \\
\hline Demands & 0.14 & 0.04 & .25 & 3.41 & .001 \\
\hline \multicolumn{6}{|c|}{ DEPRESSION } \\
\hline \multicolumn{6}{|c|}{$R^{2}=.07 ; F(1,178)=15.13 ; p=.001$} \\
\hline & $B$ & $S E$ & $\beta$ & $t$ & $p$ \\
\hline (Constant) & 15.27 & 1.30 & & 11.77 & .001 \\
\hline Inconsistency & 0.17 & 0.04 & .28 & 3.89 & .001 \\
\hline \multicolumn{6}{|c|}{ CURIOSITY } \\
\hline \multicolumn{6}{|c|}{$R^{2}=.04 ; F(1,178)=9.11 ; p=.003$} \\
\hline & $B$ & $S E$ & $\beta$ & $t$ & $p$ \\
\hline (Constant) & 32.78 & 1.14 & & 28.83 & .001 \\
\hline Inconsistency & -0.12 & 0.04 & -.22 & -3.02 & .003 \\
\hline
\end{tabular}

Note. Only significant predictors are shown.

The results show that the intensity of anxiety in women is explained by the father's inconsistency variable. The inconsistent attitude is associated with 
the Anxiety trait positively, which means that the greater Father's Inconsistency $(\beta=.31 ; p<.001)$, the greater the Anxiety trait in an adult daughter. This variable explains $10 \%$ of Anxiety variance. Anger in women is explained by the father's demanding attitude. These variables are related positively, which means that the more demanding attitude of the father $(\beta=.25 ; p<.001)$, the greater the intensity of Anger. The demands variable explains $6 \%$ of Anger variance. The trait of Depression is explained by the inconsistent attitude. They are related positively, which means that the more inconsistent attitude of the father $(\beta=.28$; $p<.001)$, the greater the Depression trait in an adult daughter. The father's inconsistency explains $7 \%$ of Depression variance. Finally, the intensity of the Curiosity traits in women is also explained by the father's inconsistent attitude. However, an inconsistent attitude is related to Curiosity negatively, which means that the more inconsistent attitude of the father $(\beta=-.22 ; p<.003)$, the lower the intensity of the Curiosity trait in his daughter. The inconsistency variable explains $4 \%$ of Curiosity variance.

\section{DISCUSSION}

The main aim of the present study was to check whether the relationship with the father (considered in terms of bonding and the father's parental attitudes) explains the intensity of anxiety, depression, anger, and curiosity traits in adult daughters. Our results showed that emotional traits in women are explained by both aspects of bonding with the father, that is, his care and control, and by only two out of five father's parental attitudes, namely, his inconsistency and demands.

Father's care turned out to be a negative predictor of Anxiety. This means that a great deal of father's care can predict a lower level of the women's anxiety trait. These results are partly supported by research which indicates that people with emotional disorders (Iniewicz et al., 2011) and internalizing symptoms (Wajda, 2013) perceive parents as less caring than people without such problems. It has been also confirmed that paternal care is associated with lower levels of generalized anxiety and anxiety before failure (Leidy et al., 2011; Pedersen, 1994; Sideridis \& Kafetsios, 2008).

Additionally, in our study Father's Care turned out to be a positive predictor of the Curiosity trait. This finding seems to be related to our previous results showing that Father's Care is a negative predictor of Anxiety. While reducing the level of anxiety, a caring father can give his daughter a sense of security. As 
a consequence, curiosity and the need of exploration can appear in children. This is consistent with research of Bowlby (2007) and Ainsworth (1982; Ainsworth \& Bell, 1970), according to which secure attachment is conducive to child's exploration. Some other studies indirectly support this line of thinking. For example, it has been shown that trait of curiosity is positively associated with well-being (Jovanovic \& Gavrilov-Jovanovic, 2014). At the same time, some studies show that paternal care is positively related to adolescents' well-being (Adamsons \& Johnson, 2013; Canetti et al., 1997; Kerr et al., 2009; Lucassen et al., 2011).

Control turned out to be a positive predictor of depression and anger traits. Similar outcomes are presented in literature. Several studies (Allen et al., 2006; Brennan et al., 2002; Hale et al., 2005; Leidy et al., 2011; Shiner \& Marmorstein, 1998) show that depression symptoms are related to the defective relationship with the father. There are also empirical data showing that the father's control is positively linked with depressive symptoms (Leidy et al., 2011; Pedersen, 1994) and a high level of anger (Muris et al., 2004). It was also found that difficulties in emotion regulation are more prevalent among adolescents with psychologically controlling fathers (McEwen \& Flouri, 2009). Some other studies have suggested that father's control is positively linked with criminal behavior of adolescents (Pedersen, 1994), social problems of adolescent girls (Wajda, 2013) and internalizing symptoms (Van Leeuwen et al., 2004). Thus, on the basis of our findings and other studies, it can be concluded that high paternal control can be conducive to depression and anger traits.

As also hypothesized, parental attitudes of the father explain the traits of emotions in adult daughters. A demanding attitude was proved to be a positive predictor of anger trait in women. These results are generally consistent with previous studies which indicate links between aggression and irritability and the father's demands (Sitarczyk, 2016).

The findings showing that the father's control and demanding attitude are positive predictors of the anger trait in adult women can be also interpreted using Bandura's (2007) theory. A father controlling his daughter may feel angry when she does not want to be controlled. It is conceivable that through the modelling mechanism, the daughter can learn from her father how to behave and how to react emotionally, which can already be shaped as a tendency to feel these emotions during adult life. Anger may also appear in response to the father's use of the demanding attitude. Fathers' excessive demands, imposing authority, imperious and domineering attitude, and imposition of restrictions on the freedom and 
initiative of others can lead to their daughters' opposition and rebellious attitude against being given orders and restrictions.

The result showing that the father's inconsistent attitude is a negative predictor of women's curiosity trait is confirmed by Bowlby's (2007) theory of attachment. It demonstrates that when the caregiver's behavior is not consistent, the child tends to be anxious and cannot explore freely.

Finally, our study shows that the father's inconsistent attitude is a positive predictor of anxiety and depression traits. The results obtained are similar to those presented in the literature, showing a link between the father's inconsistent attitude and depressive symptoms (Pasternak \& Ochojska, 2016) and the anxiety trait (Jankowska, 2014; Szczypińska, 2018). Some other studies also show that the father's inconsistent attitude is conducive to his daughter's negative assessment of her body attractiveness (Kobierecka, 2013), which is a positive predictor of depressive symptoms (Radziwiłłowicz, 2016).

The links between the father's parental attitudes and women's emotional functioning, as shown in the present study, are also supported by Plopa (2015) in theoretical foundations of his method used in this study. An inconsistent attitude is characterized by a parent's behavioral swing, which consists in accepting behaviors that are alternately imposing and limiting. The parents' inconsistency may lead to the perception of the world as chaotic, accidental, and unstructured. The lack of stability connected with an inconsistent attitude promotes inadequate self-esteem of the child and their greater tendency to feel anxiety and depression. Similarly, Antonovsky (2005) claims that lack of stability in the parents' behavior gives rise to anxiety in children. Our findings are also supported by results showing that the father's inconsistent attitude is positively associated with neuroticism in adult daughters (Plopa, 2016).

\section{CONCLUSIONS}

It should be emphasized that our research is not free from shortcomings. The first one is the nature of the group, which should be more diversified in terms of place of residence and material situation. An important limitation is also the methods we used in the study - the PBI and TPI were experimental versions. Another limitation is the fact that the participants had to assess their parental bonds and attitudes retrospectively, which may have resulted in the perception of paternal behavior in a different way than it was in reality. Therefore, further longitudinal studies in this area would be desirable in order to discover the 
mechanisms of the relationship between the father's behavior and the emotional functioning of women.

To sum up, our results indicate a significant link between the relationship with the father and the functioning of adult daughters in their emotional sphere. At the same time, this area requires further exploration. In future it would be advisable to broaden the scope of the study by including groups of adolescent girls and women in late adulthood. Another direction may be to include women with various problems, such as depression, anxiety disorders or addictions. Other measures should also be used to compare the results.

\section{REFERENCES}

Adamsons, K., \& Johnson, S. K. (2013). An updated and expanded meta-analysis of nonresident fathering and child well-being. Journal of Family Psychology, 27(4), 589-599. https://doi.org/10.1037/a0033786

Ainsworth, M. D. S. (1982). Attachment: Retrospect and prospect. In C. M. Parkes \& J. StevensonHinde (Eds.), The place of attachment in human behavior (pp. 3-30). Basic Books.

Ainsworth, M. D. S., \& Bell, S. M. (1970). Attachment, exploration, and separation: Illustrated by the behavior of one-year-olds in a strange situation. Child Development, 41(1), 49. https://doi.org/10.2307/1127388

Allen, J. P., Insabella, G., Porter, M. R., Smith, F. D., Land, D., \& Phillips, N. (2006). A socialinteractional model of the development of depressive symptoms in adolescence. Journal of Consulting and Clinical Psychology, 74(1), 55-65. https://doi.org/10.1037/0022-006X. 74.1.55

Antonovsky, A. (2005). Rozwiklanie tajemnicy zdrowia. Jak radzić sobie ze stresem i nie zachorowac [Unraveling the secret of health. How to deal with stress and not get sick]. Instytut Psychiatrii i Neurologii.

Bandura, A. (2007). Teoria społecznego uczenia się [Social learning theory]. Wydawnictwo Naukowe PWN.

Białecka-Pikul, M. (2011). Wczesne dzieciństwo [Early childhood]. In J. Trempała (Ed.), Psychologia rozwoju czlowieka (pp. 172-201). Wydawnictwo Naukowe PWN.

Bowbly, J. (1969/2007). Przywiązanie [Attachment]. Wydawnictwo Naukowe PWN.

Brennan, P. A., Katz, A. R., Hammen, C., \& Le Brocque, R. M. (2002). Maternal depression, paternal psychopathology, and adolescent diagnostic outcomes. Journal of Consulting and Clinical Psychology, 70(5), 1075-1085. https://doi.org/10.1037//0022-006X.70.5.1075

Bulik, C. M., Sullivan, P. F., Fear, J. F., \& Pickering, A. (2000). Outcome of anorexia nervosa: Eating attitudes, personality, and parental bonding. International Journal of Eating Disorders, 28(2), 139-147.

Canetti, L., Bachar, E., Galili-Weisstub, E., De-Nour, A. K., \& Shalev, A. Y. (1997). Parental bonding and mental health in adolescence. Adolescence, 32(126), 381-394.

Cattell, R. B., \& Scheier, I. H. (1960). Stimuli related to stress, neuroticism, excitation, and anxiety response patterns: Illustrating a new multivariate experimental design. The Journal of Abnormal and Social Psychology, 60(2), 195-204. https://doi.org/10.1037/h0046347 
Clark, L. A., \& Watson, D. (2012). Funkcjonalne i dysfunkcjonalne reakcje uczuciowe [Functional and dysfunctional emotional reactions]. In R. J. Davidson (Ed.), Natura emocji. Podstawowe zagadnienia (pp. 119-124). GWP.

Eisenberg, N., Fabes, R. A., \& Losowa, S. (1999a). Reakcje emocjonalne: Ich regulacja, korelaty społeczne i socjalizacja [Emotional reactions: Their regulation, social correlates and socialization]. In D. J. Salovey \& P. Sluyter (Eds.), Rozwój emocjonalny a inteligencja emocjonalna: Problemy edukacyjne (pp. 223-280). Rebis.

Eisenberg, N., Fabes, R. A., Shepard, S. A., Guthrie, I. K., Murphy, B. C., \& Reiser, M. (1999b). Parental reactions to children's negative emotions: Longitudinal relations to quality of children's social functioning. Child Development, 70(2), 513-534. https://doi.org/10.1111/ 1467-8624.00037

Hale, W. W., Van Der Valk, I., Engels, R., \& Meeus, W. (2005). Does perceived parental rejection make adolescents sad and mad? The association of perceived parental rejection with adolescent depression and aggression. Journal of Adolescent Health, 36(6), 466-474. https://doi.org/10.1016/j.jadohealth.2004.04.007

Iniewicz, G., Wiśniewska, D., Dziekan, K., \& Czuszkiewicz, A. (2011). Wzory przywiązania i zachowania agresywne wśród młodzieży $z$ diagnozą zaburzeń zachowania i emocji [Attachment patterns and aggressive behavior among adolescents with diagnosed behavioral and emotional disorders]. Psychiatria Polska, 47(5), 703-711.

Jankowska, M. (2014). Postawy rodzicielskie matki i ojca a lęk jako stan i lęk jako cecha $\mathrm{u}$ młodych dorosłych [Parental attitudes of mother and father versus anxiety-state and anxiety-trait in young adults]. Kwartalnik Naukowy Fides Es Rato, 4(18), 88-108.

Jovanovic, V., \& Gavrilov-Jovanovic, V. (2014). The good, the bad (and the ugly): The role of curiosity in subjective well-being and risky behaviors among adolescents. Personality and Social Psychology, 55(1), 38-44. https://doi.org/10.1111/sjop.12084

Józefik, B., Iniewicz, G., \& Ulasińska, R. (2010). Attachment patterns, self-esteem, gender schema in anorexia and bulimia nervosa. Psychiatria Polska, 44(5), 665-676.

Kerr, D. C. R., Capaldi, D. M., Pears, K. C., \& Owen, L. D. (2009). A prospective three generational study of fathers' constructive parenting: Influences from family of origin, adolescent adjustment, and offspring temperament. Developmental Psychology, 45(5), 12571275. https://doi.org/10.1037/a0015863

Kobierecka, A. (2013). Emocjonalny aspekt obrazu ciała a ocena relacji z rodzicami u młodych kobiet [The emotional aspect of body image and an assessment of relationships between young women and their parents]. Przeglad Psychologiczny, 55(4), 383-395.

Leidy, M. S., Schofield, T. J., Miller, M. A., Parke, R. D., Coltrane, S., Braver, S., \& Adams, M. (2011). Fathering and adolescent adjustment: Variations by family structure and ethnic background. Fathering: A journal of theory, research, and practice about men as fathers, 9(1), 44-68. https://doi.org/10.3149/fth.0901.44

Liberska, H. (2011). Teorie rozwoju psychicznego [Theories of mental development]. In J. Trempała (Ed.), Psychologia rozwoju człowieka (pp. 71-126). Wydawnictwo Naukowe PWN.

Litman, J. A., \& Spielberger, C. D. (2003). Measuring epistemic curiosity and its diversive and specific components. Journal of Personality Assessment, 80(1), 75-86. https://doi.org/10. 1207/S15327752JPA8001_16

Lucassen, N., Tharner, A., Van IJzendoorn, M. H., Bakermans-Kranenburg, M. J., Volling, B. L., Verhulst, F. C., \& Tiemeier, H. (2011). The association between paternal sensitivity and 
infant-father attachment security: A meta-analysis of three decades of research. Journal of Family Psychology, 25(6), 986-992. https://doi.org/10.1037/a0025855

Main, M., \& Solomon, J. (1986). Discovery of an insecure-disorganized/disoriented attachment pattern. In M. W. Brazelton \& T. B., Yogman (Ed.), Affective development in infancy (pp. 95-124). Ablex Publishing.

McEwen, C., \& Flouri, E. (2009). Fathers' parenting, adverse life events, and adolescents' emotional and eating disorder symptoms: The role of emotion regulation. European Child and Adolescent Psychiatry, 18, 206-216. https://doi.org/10.1007/s00787-008-0719-3

Meyer, C., \& Gillings, K. (2004). Parental bonding and bulimic psychopathology: The mediating role of mistrust/abuse beliefs. International Journal of Eating Disorders, 35(2), 229-233. https://doi.org/10.1002/eat.10236

Muris, P., Meesters, C., Morren, M., \& Moorman, L. (2004). Anger and hostility in adolescents: Relationships with self-reported attachment style and perceived parental rearing styles. Journal of Psychosomatic Research, 57(3), 257-264. https://doi.org/10.1016/S00223999(03)00616-0

O’Brien, K. M., Friedman, S. M., Tipton, L. C., \& Linn, S. G. (2000). Attachment, separation, and women's vocational development: A longitudinal analysis. Journal of Counseling Psychology, 47(3), 301-315. https://doi.org/10.1037/0022-0167.47.3.301

Olejnik, M. (2017). Średnia dorosłość [Middle adulthood]. In J. Trempała (Ed.), Psychologia rozwoju czlowieka (pp. 312-325). Wydawnictwo Naukowe PWN.

Oleś, M. (2012). Inwentarz Więzi z Rodzicami [Unpublished manuscript]. Department of Clinical Psychology, John Paul II Catholic University of Lublin.

Parker, G., Tupling, H., \& Brown, L. B. (1979). A Parental Bonding Instrument. British Journal of Medical Psychology, 52(1), 1-10. https://doi.org/10.1111/j.2044-8341.1979.tb02487.x

Pasternak, J., \& Ochojska, D. (2016). Zaburzenia psychiczne u studentów a ich retrospektywna ocena postaw rodzicielskich. Implikacje do psychoterapii [Mental disorders in students and their retrospective assessment of parental attitudes. Implications for psychotherapy]. Psychoterapia, 4(179), 87-100.

Pedersen, W. (1994). Parental relations, mental health, and delinquency in adolescents. Adolescence, 29(116), 975-990.

Plopa, M. (2015). Psychologia rodziny: Teoria i badania [Family psychology: Theory and Research]. Oficyna Wydawnicza "Impuls."

Plopa, M. (2016). Więzi w malżeństwie i rodzinie: Metody badań [Marriage and family bonds: Research methods]. Oficyna Wydawnicza "Impuls."

Poon, B. T., \& Zaidman-Zait, A. (2014). Social support for parents of deaf children: moving toward contextualized understanding. Journal of Deaf Studies and Deaf Education, 19(2), 176-188. https://doi.org/10.1093/deafed/ent041

Radziwiłłowicz, W. (2016). Wpływ wybranych czynników na nasilenie objawów depresyjnych $\mathrm{u}$ kobiet we wczesnej dorosłości [The effect of selected factors on the severity of depressive symptoms in women in early adulthood]. Psychologia Rozwojowa, 22(4), 43-54. https://doi.org/10.4467/20843879PR.16.021.5998

Roe, A., \& Siegelman, M. (1963). Parent-child relations questionnaire. Child Development, 34, $355-369$.

Scott, A. B., \& Mallinckrodt, B. (2005). Parental emotional support, science self-efficacy, and choice of science major in undergraduate women. The Career Development Quarterly, 53(3), 263-273. https://doi.org/10.1002/j.2161-0045.2005.tb00995.x 
Shiner, R. L., \& Marmorstein, N. R. (1998). Family environments of adolescents with lifetime depression: Associations with maternal depression history. Journal of the American Academy of Child and Adolescent Psychiatry, 37(11), 1152-1160.

Sideridis, G. D., \& Kafetsios, K. (2008). Perceived parental bonding, fear of failure and stress during class presentations. International Journal of Behavioral Development, 32(2), 119-130. https://doi.org/10.1177/0165025407087210

Siegelman, M. (1966). Loving and punishing parental behavior and introversion tendencies in sons. Child Development, 37, 985-992. https://doi.org/10.2307/1126620

Sitarczyk, M. (2002). Międzynarodowa transmisja postaw wychowawczych ojców [International transmission of fathers' educational attitudes]. Wydawnictwo UMCS.

Sitarczyk, M. (2016). Postawy ojcowskie a zachowania agresywne młodzieży [Paternal attitudes and aggressive behavior of youth]. Roczniki Pedagogiczne, 8(4), 83-96. https://doi.org/10. 18290/rped.2016.8(44).4-5

Sosnowski, T. (2009). Ojciec i jego rola w życiu dziecka [The father and his role in the child's life]. In W. Danilewicz (Ed.), Oblicza współczesności w perspektywie pedagogiki społecznej (pp. 199-215). Wydawnictwo Akademickie Żak.

Spielberger, C. D., \& Reheiser, E. (2003). Measuring anxiety, anger, depression and curiosity as emotional states and personality traits with the STAI, STAXI and STPI. In D. Hersen, M. Hilsenroth, \& M. Segal (Eds.), Comprehensive handbook of psychological assessment (Vol. 2, pp. 70-86). John Wiley \& Sons.

Spielberger, C. D., \& Reheiser, E. (2009). Assessment of emotions: Anxiety, anger, depression, and curiosity. Applied Psychology: Health and Well-Being, 1(3), 271-302. https://doi.org/10. 1111/j.1758-0854.2009.01017.x

Spielberger, C. D., \& Reheiser, E. C. (2004). Measuring anxiety, anger, depression and curiosity as emotional states and personality traits with the STAI, STAXI and STPI. In M. Hilsenroth, M. J. Segal, \& D. Hersen (Eds.), Comprehensive Handbook of Psychological Assessment (pp. 70-86). John Wiley \& Sons.

Spielberger, C. D., \& Starr, L. M. (1994). Curiosity and exploratory behaviour. In M. O’Neil \& H. F. Drillings, Jr (Eds.), Motivation: Theory and research. Lawrence Erlbaum Associates.

Szczypińska, M. (2018). Postawa nadmiernie wymagająca i niekonsekwentna rodziców a lęk i poczucie własnej skuteczności u zawodników w sporcie kwalifikowanym [The overly demanding and inconsistent attitude of parents and anxiety and a sense of self-efficacy in competitors in qualified sport]. Rozprawy Naukowe AWF We Wrocławiu, 62, 79-93.

Tomasiewicz, A., Matusiak, F., \& Treger, B. (2016). Doświadczenie traumy a percepcja więzi. Porównanie grup młodzieży hospitalizowanej w psychiatrycznym oddziale stacjonarnym z młodzieżą nieleczoną [The experience of trauma and the perception of attachment: A comparison of hospitalized adolescents with untreated ones]. Psychoterapia, 2(177), 87-99.

Van Leeuwen, K. G., Merivielde, I., Braet, C., \& Bosmans, G. (2004). Child personality and parental behavior as moderators of probable behavior: Variable- and person-centered approaches. Developmental Psychology, 40(6), 1028-1046. https://doi.org/10.1037/00121649.40.6.1028

Wajda, Z. (2013). Percepcja relacji między rodzicami oraz wzory przywiązania a nasilenie objawów psychopatologicznych u dziewcząt w późnej adolescencji [The perception of the relationship between parents, patterns of attachment and psychopathological symptoms in girls in late adolescence]. Psychiatria Polska, 47(5), 853-864. 
Witkowska, B. (2013). Percepcja postaw rodzicielskich a poziom samooceny dziewcząt z anoreksją psychiczną [Perception of parental attitudes and the self-esteem of adolescent girls with anorexia nervosa]. Psychiatria Polska, 47(3), 397-409.

Wrześniewski, K., \& Oleś, P. (2005). Polish version of State Trait Personality Inventory [Unpublished manuscript]. Department of Personality Psychology, John Paul II Catholic University of Lublin.

Żechowski, C., \& Namysłowska, I. (2008). Teoria przywiązania a rozwój zaburzeń psychicznych [The theory of attachment and the development of mental disorders]. In J. I. B. Józefik (Ed.), Koncepcja przywiazania - od teorii do praktyki klinicznej (pp. 53-74). Wydawnictwo UJ. 